\title{
Nutrient accumulation in bean and fruit from irrigated and non-irrigated Coffea canephora cv. Conilon
}

\author{
André Monzoli Covre', Weverton Pereira Rodrigues ${ }^{2}$, Henrique Duarte Vieira ${ }^{2}$, Heder Braun ${ }^{3}$, \\ José Cochicho Ramalho ${ }^{4,5}$, Fábio Luiz Partelli**
}

${ }^{1}$ Universidade Federal do Espírito Santo, Centro Universitário Norte do Espírito Santo, Departamento de Ciências Agrárias e Biológicas, Rodovia BR 101 Norte, Bairro Litorâneo, São Mateus, Espírito Santo, Brazil, '² Universidade Estadual do Norte Fluminense Darcy Ribeiro, Centro de Ciências e Tecnologias Agropecuárias, Avenida Alberto Lamego, Parque Califórnia, Campos dos Goytacazes, RJ, Brazil, ${ }^{3}$ Universidade Estadual do Maranhão (UEMA), Departamento de Fitotecnia e Fitossanidade, Cidade Universitária, Tirirical, Paulo VI, S/N, São Luís, Maranhão, Brasil, ${ }^{4}$ Grupo Interações Planta-Ambiente \& Biodiversidade (PlantStress\&Biodiversity), Linking Landscape, Environment, Agriculture and Food, (LEAF), Dept. Recursos Naturais, Ambiente e Território (DRAT), Instituto Superior de Agronomia (ISA), Universidade de Lisboa (ULisboa), Qta. Marquês, Av. República, Oeiras, Portugal, ${ }^{5}$ GeoBioTec, Faculdade de Ciências e Tecnologia (FCT), Universidade NOVA de Lisboa (UNL), Caparica, Portugal.

\section{A B S TR A C T}

The amount of nutrients present in husks and beans from Conilon coffee fruits directly influence the crop nutritional management, as well as its use as a complement to conventional fertilization. The present study aimed to quantify the concentration and accumulation of nutrients in husks, beans and whole fruit in irrigated and non-irrigated plants from the cropped genotype C. canephora cv. Conilon Clone 02, from clonal variety EMCAPA 8111. The experiment consisted of two treatments (irrigated and non-irrigated) in a completely randomized design with 28 replicates under field conditions, in southern Bahia, Brazil. During harvesting stage, 50 fruits per plant, in two consecutive harvests, were collected to quantify the dry matter and accumulation of nutrients in the husks, beans and fruits. The fruits from irrigated coffee plants showed higher $\mathrm{N}, \mathrm{P}, \mathrm{K}, \mathrm{Ca}, \mathrm{Mg}, \mathrm{Cu}$ and $\mathrm{Mn}$ accumulation than non-irrigated plants. The huskand beans from irrigated coffee plants showed higher $\mathrm{Ca}, \mathrm{Zn}$ and $\mathrm{Cu}$ and N, P, Ca, Mg, S, Cu and $\mathrm{Mn}$ accumulation, respectively, than non-irrigated coffee. Regarding the nutrient accumulation, $\mathrm{K}$ followed by $\mathrm{N}$, and $\mathrm{Ca}$ were the most represented macronutrients in coffee husk. $\mathrm{N}$ followed by $\mathrm{K}$ and $\mathrm{P}$, and $\mathrm{N}$ followed by $\mathrm{K}$ and $\mathrm{Ca}$ were the most represented macronutrients in beans and fruit, respectively. Fe and $\mathrm{B}$ were the micronutrients found in higher contents in husk, beans and fruits from Conilon coffee.

Keywords: Coffea canephora; Drought; Fertilizer; Nutrients accumulation

\section{INTRODUCTION}

The genus Coffea includes at least 124 species (Davis et al., 2011), among which Coffea arabica and C. canephora are the most important species used in the coffee production (Davis et al., 2012). World coffee bean production reached ca. 141.8 million bags (of $60 \mathrm{~kg}$ ) in 2014, being ca. $40 \%$ from C. canephora (ICO, 2015). Brazil is the second largest producer of $C$. canephora, with ca. 13.0 million bags of coffee beans produced in 2014 (ICO, 2015).

The Conilon coffee (Coffea canephora Pierre ex A. Froehner) is frequently grown in regions with drought incidence, which has led growers to invest more in irrigation systems.
These systems potentiate the buds production (Carvalho et al., 2006), increases the number of reproductive branches per plant (Nazareno et al., 2003) and the number of flowers in C. arabica (Massarirambi et al., 2009), while provides better fruit development and filling (Pezzopane et al., 2010). Therefore, irrigation ensures high productivity (Scalco et al., 2011; Bonomo et al., 2013; Sakai et al., 2015), and a final product with better beverage quality (Fernandes et al., 2012). However, others climatic factors can also affect significantly the coffee beverage quality (Santos et al., 2015).

The Conilon coffee shows great productive potential linked to high nutritional requirement and accumulates large amounts of nutrients in tissues (Bragança et al., 2007;

\footnotetext{
${ }^{*}$ Corresponding author:

Fábio Luiz Partelli, Universidade Federal do Espírito Santo, Centro Universitário Norte do Espírito Santo, Departamento de Ciências Agrárias e Biológicas, Bairro Litorâneo, CEP: 29932-540, São Mateus, Espírito Santo, Brazil.

E-mail: partelli@yahoo.com.br
} 
Serrano et al., 2011; Partelli et al., 2014.). The retained nutrient amounts by coffee plants changes according to the location, time of year, age, organs and the tissues within the same plant (Bragança et al., 2007) and maturation cycle (Partelli et al., 2014).

The coffee's fruiting process comprises a sequence of physiological events and morphological changes ranging from flower induction to fruit maturation, having a high demand for mineral nutrients (Carelli et al. 2006; Bragança et al, 2007; Melo et al. 2011; Partelli et al., 2014). During development, fruits are strong sinks for minerals and carbohydrates, therefore competing with other plant organs and often leading to nutritional deficiencies in those organs of the same coffee plant (Reindeer and Maestri, 1985; Carvalho et al., 1993; Laviola et al., 2008).

Physically adequate soil for coffee production can display low availability of some nutrients due to either actual deficiency or factors which limit the absorption, frequently leading to deficiency symptoms in coffee crops (Martinez et al., 2003; Partelli et al., 2006; Laviola et al., 2007a). An alternative to acceptable nutrition of crops is the use of organic nutrient sources, such as coffee husk (Serrano et al., 2011). Additionally, it has low cost, especially when the produced coffee is locally processed.

The need for renewable options, available in-situ and lower cost for the supply of nutrients for the crop is increasingly important due to the need for more sustainable agriculture (Chemura, 2014). By knowing the amounts of allocated nutrients in Conilon coffee tissues, valuable information can be gathered to assist the planning of the coffee crop fertilization program, as well as its use as a complement to conventional fertilization. Therefore, this study aims at to quantify the concentration and accumulation of nutrients in the husk, beans and fruits from irrigated and non-irrigated Conilon coffee trees.

\section{MATERIALS AND METHODS}

\section{Plant material and experimental conditions}

The experiment was performed in southern Bahia, Brazil (42'13 'S latitude and $39^{\circ} 25$ '28"W longitude) at an altitude of $108 \mathrm{~m}$. Five year old plants from C. canephora cv. EMCAPA 8111 genotypes Clone 02 (Bragança et al., 2001) grown under field conditions and spaced $3.5 \times 1.0 \mathrm{~m}$. According to Köppen classification, the climate is Aw, tropical with a dry and rainy season during the winter and summer, respectively (Köppen, 1931; Alvares et al., 2014). The soil is classified as Oxisol (sandy loam dystrophic Yellow Latosol) according to Embrapa (2013). Chemical and physical characteristics of the soil, at $0-20 \mathrm{~cm}$ layer were: P: $28.5 \mathrm{mg} \mathrm{dm}^{-3}$; K: $105 \mathrm{mg} \mathrm{dm}^{-3}$; Ca: $4.15 \mathrm{cmol}_{\mathrm{c}} \mathrm{dm}^{-3}$; Mg: $1.55 \mathrm{cmol}_{\mathrm{c}} \mathrm{dm}^{-3}$; S: $15.5 \mathrm{mg} \mathrm{dm}^{-3}$; B: $1.49 \mathrm{mg} \mathrm{dm}^{-3}$; Cu: $1.9 \mathrm{mg} \mathrm{dm}^{-3}$; Fe: $450 \mathrm{mg} \mathrm{dm}^{-3}$; Mn: $20.0 \mathrm{mg} \mathrm{dm}^{-3}$; Zn: $4.2 \mathrm{mg} \mathrm{dm}{ }^{-3}$; pH: $6.25 ; \mathrm{H}^{+}+\mathrm{Al}^{3+}: 2.85 \mathrm{cmol}_{\mathrm{c}} \mathrm{dm}^{-3}$; organic matter: 4.55 dag kg-1; total sand: $730 \mathrm{~g} \mathrm{~kg}^{-1}$; silt: $110 \mathrm{~g} \mathrm{~kg}^{-1}$; clay: $160 \mathrm{~g} \mathrm{~kg}^{-1}$; field capacity: $0.19 \mathrm{~cm}^{3} \mathrm{~cm}^{-3}$ and permanent wilting point: $0.13 \mathrm{~cm}^{3} \mathrm{~cm}^{-3}$.

A completely randomized design with two treatments (irrigated and non-irrigated) with 28 replicates under field conditions were used. The management practices on the crop consisted in weeds control through herbicides and clipping, preventive phytosanitary management, liming, fertilization and irrigation (only on irrigated treatment). To implement the non-irrigated treatment, irrigation of the respective plot was suspended in March of 2011 in order to allow the plants acclimation to drought. In the irrigated treatment, surface drip irrigation was used with one line of emitters per plants lines, spaced every $0.5 \mathrm{~m}$ and flow of $2.0 \mathrm{~L} \mathrm{~h}^{-1}$.

The air temperatures (maximum, mean and minimum), global solar radiation, rainfall and relative humidity of the air were collected at an automatic weather station located at a distance of $800 \mathrm{~m}$ from the experimental area (Fig. 1). The meteorological data were used to determine the reference evapotranspiration (ETo) according to the Penman-Monteith model (Allen et al., 1998). The irrigation management was adopted through water balance, based on crop evapotranspiration (ETc), rainfall measured at the site and water storage characteristics of soil. A daily soil water balance (for both irrigated and non-irrigated conditions) was calculated to identify water deficit periods (Fig. 1).

Both irrigated and non-irrigated treatments were fertilized annually with: $\mathrm{N}-500 \mathrm{~kg} \mathrm{ha}{ }^{-1} ; \mathrm{P}_{2} \mathrm{O}_{5}-100 \mathrm{~kg} \mathrm{ha}{ }^{-1}$; $\mathrm{K}_{2} \mathrm{O}-400 \mathrm{~kg} \mathrm{ha}^{-1}$. The fertilizer was split and applied weekly on irrigated plants, through fertigation, whereas the fertilizer was split 10 times over the two years on nonirrigated plants. The coffee crop was conducted according to programmed cycle pruning system with four orthotropic branches (Verdin Filho et al., 2014).

\section{Nutrient accumulation measurements}

The fruit samples were collected during the harvest of 2012 and 2013 (two harvests), being collected 14 samples per treatment (one per plant) in each harvest. During the harvest, 50 coffee fruits were collected in each plant, being selected only mature fruits (consisting of two beans). Harvested fruits were dried in an oven with forced air at $70{ }^{\circ} \mathrm{C}$ for $72 \mathrm{~h}$. Thereafter, the fruits were processed aiming at to separate the beans and husk. Afterward, these fruit parts were weighed on a precision balance to obtain the 


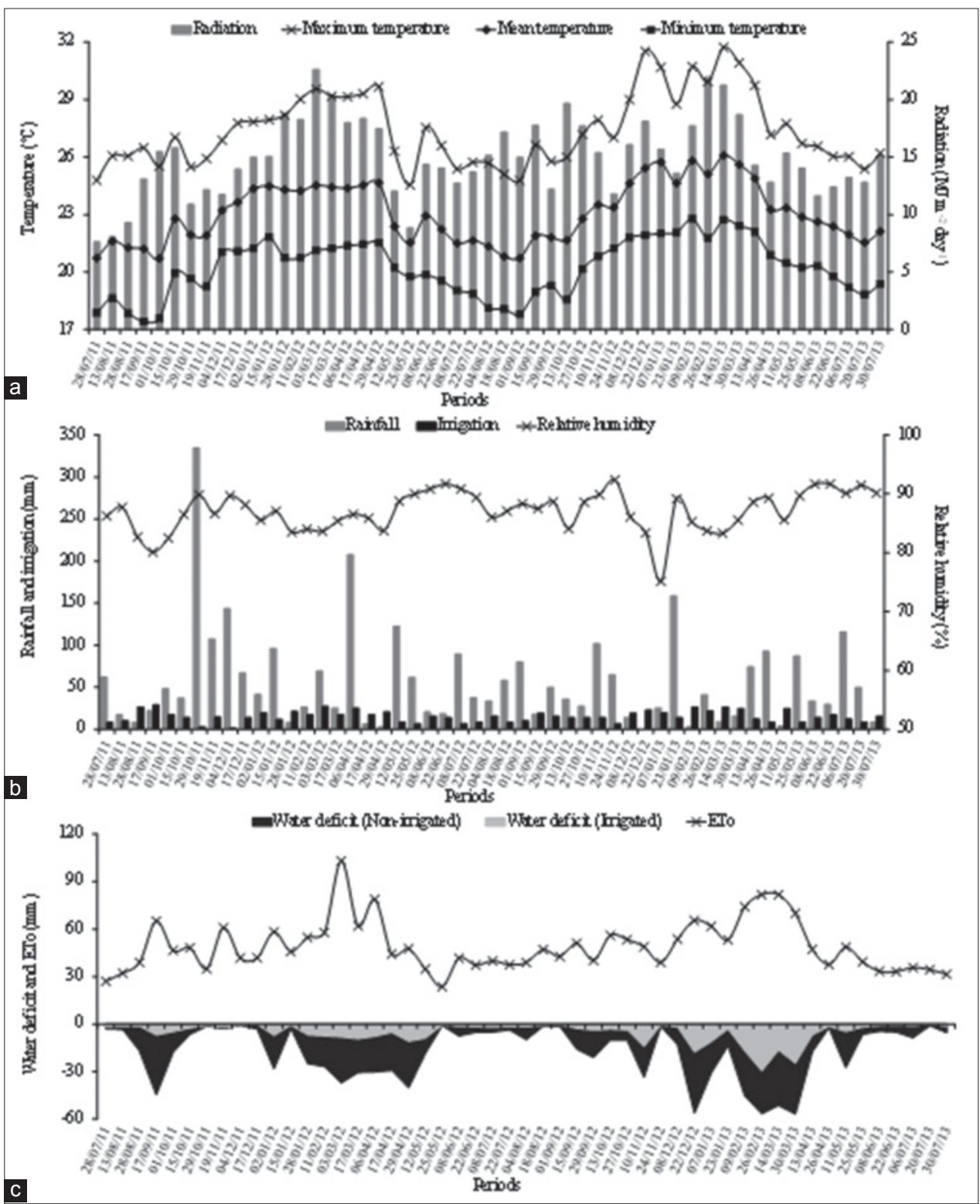

Fig 1. Global solar radiation, maximum, mean and minimum air temperatures (a); rainfall, irrigation and relative humidity (b); water deficit (in nonirrigated and irrigated treatments) and total reference evapotranspiration (ETo) (c), determined during the experimental period between July 2011 and July 2013.

straw, bean and total fruit dry mass. Thereafter, the samples (straw, bean and fruit) were finely ground in a wiley mill and used to macro (N, P, K, Ca, Mg and S) and micronutrients (Fe, $\mathrm{Zn}, \mathrm{Cu}, \mathrm{Mn}$ and $\mathrm{B}$ ) analysis following the methodology described by Silva et al. (2009).

The amount of husk and bean dry mass in a processed bag of $60 \mathrm{~kg}$ of coffee was estimated, considering the relationship found between bean and straw from fruit. Accumulation of macro and micronutrients in the husk and beans were calculated by dry mass $\mathrm{x}$ the concentration of each nutrient. Macro and micronutrients accumulated in the fruits were obtained from the sum of the macro and micronutrients contained in the husk and bean. All data were submitted to a one-way ANOVA, followed by a mean using the Student's t-test, using Genes software (Cruz, 2013). A 95\% confidence level was adopted for all tests.

\section{RESULTS AND DISCUSSION}

The maintenance of an adequate mineral nutrition and of the balance between the several minerals is crucial to plant development. Such preservation of adequate mineral contents and balance within the plant is determinant for the expression of stress tolerance mechanisms on coffee (Ramalho et al., 2013), and assume a particular importance under predicted future conditions of climate changes and global warming (Martins et al., 2014), which are expected 
to simultaneously alter temperature and water availability to main crops, including to coffee (Rodrigues et al., 2016).

The concentration and accumulation of nutrients in Conilon coffee showed no statistical differences between water treatments in husk, beans and the whole fruit (Table 1). Fruit dry mass production of Conilon coffee is not mainly influenced by the drought (non-irrigated plants) at the end of fruits physiological maturity stage (Table 1). The production of one ton $(1000 \mathrm{~kg})$ processed Conilon coffee resulted in production of 520.7 and $536.7 \mathrm{~kg}$ of husks by irrigated and non-irrigated plants, respectively (Table 1). Therefore, for each produced bag, the husk biomass represented $c a$. half of processed bean biomass, representing $c a .35 \%$ and. $65 \%$ of total fruit biomass, respectively, what agrees with Matiello et al. (2010) who claim that $2 \mathrm{~kg}$ Conilon coffee beans yields $1.3 \mathrm{~kg}$ of processed coffee. To the high yield of genotype 02 found here it would have contributed that only with perfect coffee fruit were used, that is, from flowers which undergone complete syngamy with fertilization of the two ovules of flower. Additionally, the genotype 02 shows low proportion of "moca" beans (Pereira, 2015). These values are somewhat higher than those found for $C$. arabica genotypes that showed values in the range of $c a .43 \%$ to $59 \%$ of coffee beans yields to processed coffee (Gaspari-Pezzopane et al., 2005; Matiello et al., 2010; Palva et al., 2010).

As regards the mineral contents in the fruit tissues, the macronutrient concentration of husk and beans showed no statistical difference between the irrigated and non-irrigated treatments, except for P concentration in the husk where non-irrigated plants presented a $33.3 \%$ higher value than irrigated plants (Table 2). This contrasted with the impact of extreme temperatures in mineral contents at leaf level (Ramalho et al., 2013; Martins et al., 2014), and might be linked to the strong sink effect of the fruits that could withdraw minerals from other plant organs, together with the mineral availability provided by the applied fertilization in the present experiments.

The largest macronutrients concentrations in the coffee husk, in decreasing order, were $\mathrm{K}, \mathrm{N}$ and $\mathrm{Ca}$, whereas in beans were $\mathrm{N}, \mathrm{K}$ and $\mathrm{P}$. These macronutrients in the husk and beans showed no statistical difference between water availability treatments (Table 2). Regarding to micronutrients, Fe was by far the most represented mineral both in husk and in beans (Table 2). Therefore, the incorporation of husk in the soil would constitute an important source of some minerals, with emphasis to $\mathrm{N}$ and $\mathrm{K}$ among macronutrients, and $\mathrm{Fe}$ and $\mathrm{B}$ among micronutrients.

Considering the whole fruit, there is a significant accumulation of $\mathrm{Ca}, \mathrm{Zn}$ and $\mathrm{Cu}$ in husk from irrigated
Table 1: Husk, bean and whole fruit dry matter from irrigated and non-irrigated Conilon coffee

\begin{tabular}{|c|c|c|c|}
\hline \multirow[t]{2}{*}{ Treatment } & \multicolumn{3}{|c|}{ Dry matter per fruit (mg fruit $\left.{ }^{-1}\right)$} \\
\hline & Husks & Beans $^{1}$ & Fruit \\
\hline Irrigated & $99.3 a$ & $193.9 a$ & $293.2 a$ \\
\hline Non-irrigated & $96.8 \mathrm{a}$ & $182.9 a$ & $279.7 a$ \\
\hline $\mathrm{CV}(\%)$ & 21.1 & 11.8 & 12.0 \\
\hline \multirow[t]{2}{*}{ Treatment } & \multicolumn{3}{|c|}{ Dry matter per ton of fruits $\left(\mathrm{Kg} \mathrm{ton}^{-1}\right)$} \\
\hline & Husks & Beans & Fruit \\
\hline Irrigated & 520.7 & 1000.0 & 1520.7 \\
\hline Non-irrigated & 536.7 & 1000.0 & 1536.7 \\
\hline
\end{tabular}

The values represent the mean $(n=28)$. Means followed by the same letter do not differ at $5 \%$ probability by " $t$ " test. 1Just fruit consisting of two beans was considered

Table 2: Macronutrients and micronutrients concentrations in husk and beans from irrigated and non-irrigated Conilon coffee

\begin{tabular}{|c|c|c|c|c|c|c|}
\hline \multirow[t]{2}{*}{ Treatment } & \multicolumn{6}{|c|}{ Macronutrients $\left(\mathrm{g} \mathrm{kg}^{-1}\right)$} \\
\hline & $\mathbf{N}$ & $\mathbf{P}$ & K & $\mathrm{Ca}$ & $\mathrm{Mg}$ & $s$ \\
\hline \multicolumn{7}{|l|}{ Husks } \\
\hline Irrigated & $12.8 \mathrm{a}$ & $0.8 b$ & $17.6 a$ & $4.5 \mathrm{a}$ & $0.8 a$ & $1.8 \mathrm{a}$ \\
\hline Non-irrigated & $12.5 a$ & $1.2 \mathrm{a}$ & $16.5 a$ & $4.0 \mathrm{a}$ & $0.8 a$ & $2.2 \mathrm{a}$ \\
\hline CV (\%) & 9.4 & 26.6 & 9.4 & 32.3 & 40.2 & 64.3 \\
\hline \multicolumn{7}{|l|}{ Beans } \\
\hline Irrigated & $26.7 a$ & $2.7 a$ & $16.9 a$ & $2.1 \mathrm{a}$ & $1.3 a$ & $1.8 \mathrm{a}$ \\
\hline Non-irrigated & $25.8 a$ & $1.8 \mathrm{a}$ & $17.0 \mathrm{a}$ & $1.5 \mathrm{a}$ & $1.3 a$ & $1.6 \mathrm{a}$ \\
\hline CV (\%) & 10.6 & 73.7 & 18.1 & 68.1 & 44.1 & 22.7 \\
\hline \multirow[t]{2}{*}{ Treatment } & \multicolumn{6}{|c|}{ Micronutrients $\left(\mathrm{mg} \mathrm{kg}^{-1}\right)$} \\
\hline & $\mathrm{Fe}$ & $\mathrm{Zn}$ & $\mathrm{Cu}$ & Mn & B & \\
\hline \multicolumn{7}{|l|}{ Husk } \\
\hline Irrigated & $48.2 a$ & $7.67 a$ & $6.67 a$ & $9.17 \mathrm{a}$ & $27.3 a$ & \\
\hline Non-irrigated & $56.3 a$ & $6.50 \mathrm{a}$ & $5.33 a$ & $9.00 \mathrm{a}$ & $29.3 a$ & \\
\hline CV (\%) & 74.90 & 77.90 & 57.90 & 19.30 & 36.90 & \\
\hline \multicolumn{7}{|l|}{ Beans } \\
\hline Irrigated & $55.0 a$ & $6.67 a$ & $13.2 \mathrm{a}$ & $9.50 a$ & $12.3 a$ & \\
\hline Non-irrigated & $59.0 a$ & $7.33 a$ & $11.8 \mathrm{a}$ & $7.83 a$ & $21.3 a$ & \\
\hline CV (\%) & 49.20 & 52.00 & 70.40 & 20.80 & 61.80 & \\
\hline
\end{tabular}

The values represent the mean $(n=6)$. Means followed by the same letter do not differ at $5 \%$ probability by " $\mathrm{t}$ " test

coffee (Table 3). Unlike, larger accumulated amount of $\mathrm{P}, \mathrm{S}$ and $\mathrm{Fe}$ were found in the husk from non-irrigated plants. There was larger $\mathrm{N}, \mathrm{P}, \mathrm{Ca}, \mathrm{Mg}$ and $\mathrm{S}$ accumulation in the beans from irrigated plants than non-irrigated plants. Regarding the fruit, irrigated plants showed greater accumulation of $\mathrm{N}, \mathrm{P}, \mathrm{K}, \mathrm{Ca}, \mathrm{Mg}, \mathrm{Cu}$ and $\mathrm{Mn}$, however, lower $\mathrm{B}$ accumulation (Table 3 ). The $\mathrm{K}$ macronutrient was found in larger quantity in the husk from one coffee fruit, followed by the $\mathrm{N}$ and $\mathrm{Ca}$ (Table 3). Unlike, the $\mathrm{N}$, followed by $\mathrm{K}$ were the nutrients that showed the largest accumulation in both beans and fruit.

Fe was the most abundant micronutrient in the husk, beans and whole fruit (Table 3), what agrees with the finding of Bragança et al. (2007). Furthermore, Covre et al. (2013) observed that $\mathrm{Fe}$ was the most represented micronutrient in some tissues of six months old seedlings of Conilon 
Table 3: Amount of nutrients found in husk, beans and whole fruit from irrigated and non-irrigated Conilon coffee, per fruit

\begin{tabular}{|c|c|c|c|c|c|c|}
\hline \multirow[t]{2}{*}{ Treatment } & \multicolumn{6}{|c|}{$\begin{array}{l}\text { Accumulation of macronutrients } \\
\left.\text { (mg fruit }{ }^{-1}\right)\end{array}$} \\
\hline & $\mathrm{N}$ & $\mathbf{P}$ & $K$ & $\mathrm{Ca}$ & Mg & $\mathrm{s}$ \\
\hline \multicolumn{7}{|c|}{ Husk from one fruit } \\
\hline Irrigated & $1.28 \mathrm{a}$ & $0.08 b$ & $1.76 a$ & $0.45 a$ & $0.08 a$ & $0.18 b$ \\
\hline Non-irrigated & $1.22 \mathrm{a}$ & $0.12 \mathrm{a}$ & $1.60 \mathrm{a}$ & $0.39 b$ & $0.08 a$ & $0.21 a$ \\
\hline CV (\%) & 20.5 & 20.2 & 20.5 & 20.5 & 20.9 & 20.4 \\
\hline \multicolumn{7}{|c|}{ Beans from one fruit ${ }^{1}$} \\
\hline Irrigated & $5.16 a$ & $0.53 a$ & $3.27 a$ & $0.41 \mathrm{a}$ & $0.25 a$ & $0.34 a$ \\
\hline Non-irrigated & $4.71 b$ & $0.34 b$ & $3.09 a$ & $0.26 b$ & $0.23 b$ & $0.30 \mathrm{~b}$ \\
\hline CV (\%) & 11.7 & 11.0 & 11.9 & 13.6 & 11.3 & 12.1 \\
\hline \multicolumn{7}{|l|}{ Fruit } \\
\hline Irrigated & $6.44 a$ & $0.61 a$ & $5.03 a$ & $0.86 a$ & $0.33 a$ & $0.52 a$ \\
\hline Non-irrigated & $5.93 b$ & $0.46 b$ & $4.69 b$ & $0.65 b$ & $0.31 b$ & $0.51 \mathrm{a}$ \\
\hline CV (\%) & 11.3 & 11.0 & 11.9 & 13.6 & 11.4 & 12.2 \\
\hline \multirow[t]{2}{*}{ Treatment } & \multicolumn{5}{|c|}{$\begin{array}{l}\text { Accumulation of micronutrients } \\
\left(\mu \text { fruit }^{-1}\right)\end{array}$} & \\
\hline & $\mathrm{Fe}$ & $\mathrm{Zn}$ & $\mathrm{Cu}$ & Mn & B & \\
\hline \multicolumn{7}{|c|}{ Husks from one fruit } \\
\hline Irrigated & $4.82 \mathrm{~b}$ & $0.77 a$ & $0.67 a$ & $0.92 a$ & $2.85 a$ & \\
\hline Non-irrigated & $5.48 \mathrm{a}$ & $0.63 b$ & $0.52 b$ & $0.88 a$ & $2.73 a$ & \\
\hline CV (\%) & 20.4 & 20.6 & 20.8 & 20.4 & 20.4 & \\
\hline \multicolumn{7}{|c|}{ Beans from one fruit } \\
\hline Irrigated & $10.75 a$ & $1.34 \mathrm{a}$ & $2.55 a$ & $1.84 \mathrm{a}$ & $2.39 b$ & \\
\hline Non-irrigated & $10.65 a$ & $1.29 a$ & $2.16 b$ & $1.43 b$ & $3.89 a$ & \\
\hline CV (\%) & 11.9 & 11.9 & 11.6 & 11.6 & 13.1 & \\
\hline \multicolumn{7}{|l|}{ Fruit } \\
\hline Irrigated & $15.46 a$ & $2.06 \mathrm{a}$ & $3.21 \mathrm{a}$ & $2.76 \mathrm{a}$ & $5.12 b$ & \\
\hline Non-irrigated & $16.22 a$ & $1.97 a$ & $2.67 \mathrm{~b}$ & $2.30 \mathrm{~b}$ & $6.74 a$ & \\
\hline CV (\%) & 12.0 & 12.0 & 11.1 & 11.8 & 13.6 & \\
\hline
\end{tabular}

The values represent the mean $(n=28)$. Means followed by the same letter do not differ at $5 \%$ probability by " $\mathrm{t}$ " test. 'Just fruit consisting of two beans was considered

coffee, whereas Marré (2012) reported that this mineral showed the highest micronutrient contents in fruits of some Conilon genotypes with different maturation cycles.

The results obtained for $\mathrm{N}$ are in accordance with Arzolla et al. (1963), who states that the coffee bean has a larger amount of $\mathrm{N}$ compared to husk. On the other hand, our data differ from that obtained by preview cited authors as they found greater $\mathrm{K}$ amount in the husk than bean. This difference may be related to the studied species. Except for $\mathrm{Ca}$ and $\mathrm{B}$, the analyzed nutrients are in greater quantity in the bean than husk. However, the coffee husk can present large quantity of carbohydrates, proteins, tannins + polyphenols (Lima et al., 2014).

$\mathrm{N}$ is one of the more required nutrients for production at many coffee regions (Malta et al., 2003), which is the most accumulated macronutrient by the coffee Conilon trees and seedlings (Bragança et al., 2008; Covre et al., 2013), which demonstrates the high demand for nitrogen by the coffee plants. The $\mathrm{N}$ accumulation in the Conilon coffee fruits presents significant increases between rapid expansion, filling and maturation stages (Covre and Partelli, 2013; Partelli et al., 2014).

Among the micronutrients, Fe had a larger accumulation in the fruit, husk and beans (Table 3), a fact also observed by Sarruge et al. (1966), in arabica coffee. B was the second largest accumulated micronutrient in husk and one single coffee bean followed by Mn (Table 3). On the other hand, Sarruge et al. (1966) observed that Mn was the second most micronutrient accumulated in the coffee husk followed by $\mathrm{B}$, however they observed that $\mathrm{Zn}$ was the second most micronutrient accumulated by beans, whereas in the present study, Zn was only the fourth most micronutrient accumulated in Conilon coffee beans. According to Bragança et al. (2007), B is the third most micronutrient accumulated by Conilon coffee. Accordingly, it was found that the proportion of $\mathrm{B}$ and $\mathrm{Zn}$ accumulation in fruit was higher compared to the other micronutrient during the initial growth stage of fruit expansion (Laviola et al., 2007b). This would be related to the importance of these nutrients in the cell division process and stabilization of new cell membranes (Marenco and Lopes, 2005; Laviola et al., 2007b). The differences observed between the results from this study and preview cited reports seems to be related to plant genetics/evaluated fruit, local effect and management, as well as soil fertility, water availability, among others.

Amongst minerals, $\mathrm{K}$ showed the largest mineral accumulation in husk (and the second in beans) for both water treatments, considering the production of one processed ton $(1000 \mathrm{~kg}$ ) (Table 4). In the beans, $\mathrm{N}$ was the highest accumulated mineral. Considering the entire fruit $\mathrm{N}$ and $\mathrm{K}$ are the highest accumulated macronutrients, without clear differences between water availability treatments.

Regarding the micronutrients, in the husk Fe was the most accumulated mineral (followed by B), with non-irrigated plants showing a $20 \%$ higher value than the irrigated plants. In the bean, $\mathrm{Fe}$ was also the greatest accumulated micronutrient. B accumulated $c a .73 \%$ more under water shortage conditions than in well-watered conditions. As a consequence, when considering the whole fruit, $\mathrm{Fe}$ and $\mathrm{B}$ were the most accumulated micronutrients, although the non-irrigated plants showed a tendency to higher values of both elements (Table 4).

Nutrients are accumulated by the fruit during its development, from ovule fertilization in different amounts. To produce one processed ton $(1000 \mathrm{~kg})$ of Conilon coffee, there was the following descending order of nutrient accumulation in the coffee husk: $\mathrm{K}>\mathrm{N}>\mathrm{Ca}>$ $\mathrm{S}>\mathrm{P}>\mathrm{Mg}$ and $\mathrm{Fe}>\mathrm{B}>\mathrm{Mn}>\mathrm{Zn}>\mathrm{Cu}$. In coffee beans, 


\begin{tabular}{|c|c|c|c|c|c|c|}
\hline \multirow[t]{2}{*}{ Treatment } & \multicolumn{6}{|c|}{$\begin{array}{l}\text { Accumulation of macronutrients per ton of } \\
\text { fruits }\left(\mathrm{Kg} \mathrm{ton}^{-1}\right)\end{array}$} \\
\hline & $\mathrm{N}$ & $\mathbf{P}$ & $\mathbf{K}$ & $\mathrm{Ca}$ & $\mathrm{Mg}$ & $\mathrm{s}$ \\
\hline \multicolumn{7}{|l|}{ Husks } \\
\hline Irrigated & 6.7 & 0.4 & 9.2 & 2.3 & 0.4 & 0.9 \\
\hline Non-irrigated & 6.7 & 0.6 & 8.8 & 2.2 & 0.4 & 1.2 \\
\hline \multicolumn{7}{|l|}{ Bean } \\
\hline Irrigated & 26.7 & 2.7 & 16.9 & 2.1 & 1.3 & 1.8 \\
\hline Non-irrigated & 25.9 & 1.9 & 17.0 & 1.5 & 1.3 & 1.6 \\
\hline \multicolumn{7}{|l|}{ Fruit } \\
\hline Irrigated & 33.3 & 3.2 & 26.0 & 4.4 & 1.7 & 2.7 \\
\hline Non-irrigated & 32.6 & 2.5 & 25.8 & 3.6 & 1.7 & 2.8 \\
\hline \multirow[t]{2}{*}{ Treatment } & \multicolumn{6}{|c|}{$\begin{array}{l}\text { Accumulation of micronutrients per } \\
\text { ton of fruits }\left(\mathrm{g} \mathrm{ton}^{-1}\right)\end{array}$} \\
\hline & $\mathrm{Fe}$ & $\mathrm{Zn}$ & $\mathrm{Cu}$ & Mn & B & \\
\hline \multicolumn{7}{|l|}{ Husks } \\
\hline Irrigated & 25.1 & 4.0 & 3.5 & 4.8 & 14.2 & \\
\hline Non-irrigated & 30.2 & 3.5 & 2.9 & 4.8 & 15.7 & \\
\hline \multicolumn{7}{|l|}{ Bean } \\
\hline Irrigated & 55.0 & 6.7 & 13.2 & 9.5 & 12.3 & \\
\hline Non-irrigated & 59.0 & 7.3 & 11.8 & 7.8 & 21.3 & \\
\hline \multicolumn{7}{|l|}{ Fruit } \\
\hline Irrigated & 80.1 & 10.7 & 16.6 & 14.3 & 26.6 & \\
\hline Non-irrigated & 89.2 & 10.8 & 14.7 & 12.7 & 37.1 & \\
\hline
\end{tabular}

The values represent the mean $(n=28)$

the accumulation order was $\mathrm{N}>\mathrm{K}>\mathrm{P}>\mathrm{Ca}>\mathrm{S}>\mathrm{Mg}$ and $\mathrm{Fe}>\mathrm{B}>\mathrm{Cu}>\mathrm{Mn}>\mathrm{Zn}$ and by the coffee fruits was $\mathrm{N}>\mathrm{K}>\mathrm{Ca}>\mathrm{P}>\mathrm{S}>\mathrm{Mg}$ and $\mathrm{Fe}>\mathrm{B}>\mathrm{Cu}>\mathrm{Mn}>\mathrm{Zn}$ (see Table 4). These results are very relevant, because it can be used for calculating the nutrients export according to crop productivity and to calculate what part of the crop requirement nutrition can be provided by use of husk as a nutrients source for the Conilon coffee plants.

During the coffee fruiting stage, the fruits are preferred sinks among the parts of a plant for nutrient, leading often to the deficiency in other organs of plants (Reindeer and Maestri, 1985; Carvalho et al., 1993; Laviola et al., 2008), requiring the providing through of fertilization. Coupled with high demand for fertilizers, it's the high its cost, which makes the supply of the correct amount of nutrients for crop a limitation for farmers (Serrano et al., 2011). The use of organic sources, such as coffee husk, can be an alternative to reduce the amount of mineral fertilizers provided to the coffee plantations and can reduce the fertilization cost.

The coffee husk is a byproduct generated during the coffee processing, which is discarded in many properties, or is used for feeding stoves during the drying process of coffee beans in rotary dryers. The results of this study reinforce the use of straw as fertilizer, as it has large amounts of nutrients.
Thus, the coffee straw/husk when applied to the crops can constitute an excellent complement of nutrients source, as well as of organic matter added to the soil. According to Fernandes et al. (2013), the coffee straw/husk can be used as a $\mathrm{N}, \mathrm{P}, \mathrm{K}$ and $\mathrm{S}$ source, with consequent reduction of the need of chemical fertilization regarding these nutrients, and promoting yield enhancements up to $25 \%$. Finally, decomposition of the coffee straw/husks can improve the soil physical structure, providing CTC and soil $\mathrm{pH}$ increases (Pace et al., 1996).

\section{CONCLUSIONS}

In conclusion, irrigated coffee plants showed larger accumulation of most macronutrients and some micronutrients (mainly $\mathrm{Cu}, \mathrm{Mn}$ and $\mathrm{Zn}$ ) in fruits, beans and husk. $\mathrm{K}$ followed by $\mathrm{N}$ and $\mathrm{Ca}$ were the most macronutrients found in coffee straw, whilst $\mathrm{N}$ followed by $\mathrm{K}$ and $\mathrm{P}$, and $\mathrm{N}$ followed by $\mathrm{K}$ and $\mathrm{Ca}$ were the most macronutrients found in the beans and fruit respectively. $\mathrm{Fe}$ and $\mathrm{B}$ are the most micronutrients that accumulate in the straw, beans and fruits from Conilon coffee plants.

\section{ACKNOWLEDGEMENTS}

The authors wish to thank Universidade Federal do Espírito Santo, Conselho Nacional de Desenvolvimento Científico e Tecnológico (CNPq) and Ademir Trevizani, Daniel Trevizani and Luiz Antônio Covre for supplying the coffee samples.

\section{Authors' contributions}

Study concept and management: (A. M. C., F. L. P.). Conducted the experiments: (A. M. C., F. L. P.). Analysis and interpretation of data: (A. M. C., F. L. P., H. B., H. D. V., W. P. R., J. C. R.). Wrote the manuscript: (A. M. C., F. L. P., H. B., H. D. V., W. P. R., J. C. R.). Review of manuscript at final version (F. L. P., W. P. R., J. C. R.).

\section{REFERENCES}

Alvares, C. A., J. L. Stape, P. C. Sentelhas, J. L. M. Gonçalves and G. Sparovek. 2014. Köppen's climate classification map for Brazil. Met. Zeits. 22: 711-728.

Arzolla, S., L. Gomes, J. R. Sarruge, R. G. Andrade, E. A. Graner and E. Malavolta. 1963. Studies on the mineral of the coffee supply, $X$. macronutrients extraction at harvest by Mundo Novo, Caturra e Bourbon Amarelo varieties [Estudos sobre a alimentação mineral do cafeeiro, $X$. Extração de macronutrientes na colheita pelas variedades Mundo Novo, Caturra e Bourbon Amarelo] [Port.]. Anais da Escola Superior de Agricultura Luiz de Queiroz. São Paulo, Brazil.

Bonomo, D. Z., R. Bonomo, F. L. Partelli, J. M. Souza and M. Magiero. 2013. Conilon coffee answers to different irrigation. 
[Desenvolvimento vegetativo do cafeeiro Conilon submetido a diferentes lâminas de irrigação][Port.]. Rev. Bras. Agric. Irrig. 7: 157-169.

Bragança, S. M., C. H. S. Carvalho, A. F. A. Fonseca and R. G. Ferrão. 2001. Clonal varieties of Conilon coffee for the Espírito Santo State, Brazil [Variedades clonais de café Conilon para o Estado do Espírito Santo][Port.]. Pesq. Agropec. Bras. 36: 765-770.

Bragança, S. M., H. E. P. Martinez, H. G. Leite, L. P. Santos, C. S. Sediyama, V. V. H. Alvarez and J. A. Lani. 2007. B, Cu, Fe, Mn and $\mathrm{Zn}$ accumulation by Conilon coffee plant [Acúmulo de B, $\mathrm{Cu}, \mathrm{Fe}, \mathrm{Mn}$ E Zn pelo cafeeiro Conilon][Port.]. Rev. Ceres. 54: 398-404.

Bragança, S. M., H. E. P. Martinez, H. G. Leite, L. P. Santos, C. S. Sediyama, V. V. H. Alvarez and J. A. Lani. 2008. Accumulation of macronutrients for the conilon coffee tree. J. Plant Nutr. 3: 103-120.

Carelli, M. L., J. I. Fahl and J. C. Ramalho. 2006. Aspects of nitrogen metabolism in coffee plants. Braz. J. Plant Physiol. 18(1): 9-21.

Carvalho, C. H. M., A. Colombo, M. S. Scalco and A. R. Morais. 2006. Coffee tree (Coffea arabica L.) growth at high and low planting densities under different irrigation regimes [Evolução do crescimento do cafeeiro (Coffea arabica L.) irrigado e não irrigado em duas densidades de plantio][Port.]. Cien. Agrotec. 30: 243-250.

Carvalho, C. H. S., A. B. Rena, A. A. Pereira and A. T. Cordeiro. 1993. Relationship between crop load, N, P, K, Ca, Mg and starch content, and the dieback of Catimor (Coffea arabica L.) [Relação entre produção, teores de N, P, Ca, Mg, amido e seca de ramos do Catimor (Coffea arabica L.)][Port.]. Pesq. Agropec. Bras. 28: 665-673.

Chemura, A. 2014. The growth response of coffee (Coffea arabica L.) plants to organic manure, inorganic fertilizers and integrated soil fertility management under different irrigation water supply levels. Int. J. Rec. Organ. W. Agric. 59: 1-9.

Covre, A. M., F. L. Partelli, A. L. Mauri and M. A. Dias. 2013 Initial growth and development of Conilon coffee genotypes [Crescimento e desenvolvimento inicial de genótipos de café Conilon][Port.]. Rev. Agroambiente. 7: 193-202.

Covre, A. M. and F. L. Partelli. 2013. Nitrogen in leaves and fruits of coffee conilon irrigated and not irrigated, in the state of Bahia. [Nitrogênio em folhas e frutos de café conilon irrigado e não irrigado, no estado da Bahia] [Port.]. VIII Simpósio Brasileiro de Pesquisas dos Cafés do Brasil Embrapa café, Brasília, Brazil CD-ROM.

Cruz, C. D. 2013. Genes: A software package for analysis in experimental statistics and quantitative genetics. Acta Sci. Agron. 35: 271-276.

Davis, A. P., J. Tosh, N. Ruch and M. F. Fay. 2011. Growing coffee: Psilanthus (Rubiaceae) subsumed on the basis of molecular and morphological data implications for the size, morphology, distribution and evolutionary history of Coffea. Bot. J. Linn. Soc. 167: 357-377.

Davis, A. P., T. W. Gole, S. Baena and J. Moat. 2012. The impact of climate change on indigenous Arabica coffee (Coffea arabica): Predicting future trends and identifying priorities. PLoS One. 7: 1-13.

Embrapa. Centro Nacional de Pesquisa de Solos (Rio de Janeiro, $\mathrm{RJ}$ ). Brazilian system of soil classification [Sistema brasileiro de classificação de solos][Port.]. Rio de Janeiro, Brazil.

Fernandes, A. L. T., F. Santinato, R. T. Ferreira and R. Santinado. 2013. Reduction of mineral fertilization of arabic coffee using coffee straw [Redução da adubação mineral do cafeeiro Arábica com a utilização de palha de café][Port.]. Coffee Sci. 8: 324-336.
Fernandes, A. L. T., F. L. Partelli, R. Bonomo and A. A. Golynski. 2012. The modern coffee planting in the Brazilian savannah [A moderna cafeicultura dos cerrados brasileiros][Port.]. Pesq. Agropec. Trop. 42: 231-240.

Gaspari-Pezzopane, C., H. P. Medina Filho, R. Bordignon, W. J. Siqueira, L. A. Ambrósio and P. Mazzafera, P. 2005. Environmental influences on the intrinsic outturn of coffee [Influências ambientais no rendimento intrínseco do café][Port.]. Bragantia. 64: 39-50.

ICO - International Coffee Organization. 2015. Statistics. Available from: http://www.ico.org/historical/2010-19/pdf/tot production. pdf. [Last accessed on 2015 Aug 11].

Köppen,W. 1931. Climatologia. Fundo de Cultura Econômica, México.

Laviola, B. G., H. E. P. Martinez, L. C. C. Salomão, C. D. Cruz, S. M Mendonça and L. D. S. Rosado. 2008. Accumulation in fruits and variation in the contents in leave of NPK in coffee plant cultivated in four altitudes [Acúmulo em frutos e variação na concentração foliar de NPK em cafeeiro cultivado em quatro altitudes][Port.]. Biosci. J. 24: 19-31.

Laviola, B. G., H. E. P. Martinez, L. C. C. Salomão, C. D. Cruz, S. M Mendonça and L. D. S. Rosado. 2007a. Nutrient accumulation in coffee fruits at two at two plantation altitudes: Micronutrients [Acúmulo de nutrientes em frutos de cafeeiro em duas altitudes de cultivo: Micronutrientes][Port.]. Rev. Bras. Cien. Solo. 31: 1439-1449.

Laviola, B. G., H. E. P. Martinez, L. C. C. Salomão, C. D. Cruz, S. M Mendonça and L. D. S. Rosado. 2007b. Nutrient accumulation in coffee fruits at four plantations altitude: calcium, magnesium and sulfur [Acúmulo de nutrientes em frutos de cafeeiro em quatro altitudes de cultivo: Cálcio, magnésio e enxofre][Port.]. Rev. Bras. Cien. Solo. 31: 1451-1462.

Lima, L. K. S., C. C. Santos, M. C. F. Moura, A. S. Dutra and A. F. Oliveira Filho. 2014. Use of waste derived from roasting coffee in agriculture replacing conventional fertilization [Utilização de resíduo oriundo da torrefação do café na agricultura em substituição a adubação convencional][Port.]. Agropecu. Ci. Semiárido 10: 14-19.

Malta, M. R., F. D. Nogueira and P. T. G. Guimarães. 2003. Chemical composition, yield and quality of the fertilized coffee with different sources and doses of nitrogen [Composição química, produção e qualidade do café fertilizado com diferentes fontes e doses de nitrogênio][Port.]. Cien. Agrotec. 27: 1246-1252.

Marenco, R. A. and N. F. Lopes. 2005. Plant physiology: Photosynthesis, respiration, water relations and mineral nutrition [Fisiologia vegetal: Fotossíntese, respiração, relações hídricas e nutrição mineral][Port.]. Universidade Federal de Viçosa, Brazil.

Marré, W. B. 2012. Growing and accumulation of nutrients by Conilon coffee, with distinct periods of maturation [Crescimento vegetativo e acúmulo de nutrientes em diferentes genótipos do cafeeiro Conilon][Port.]. Master. Dissertation, Universidade Federal do Espírito Santo, Vitória, Brazil.

Martinez, H. E. P., J. F. S. Menezes, R. B. Souza, V. V. H. Alvarez and P. T. G. Guimarães. 2003. Critical nutrient ranges and evaluation of nutritional status in coffee-tree plantations of Minas Gerais [Faixas críticas de concentrações de nutrientes e avaliação do estado nutricional de cafeeiros em quatro regiões em Minas Gerais][Port.]. Pesq. Agropec. Bras. 38: 703-713.

Martins, L. D., M. A. Tomaz, F. C. Lidon, F. M. DaMatta and J. C. Ramalho. 2014. Combined effects of elevated [CO2] and high temperature on leaf mineral balance in Coffea spp. plants. Clim. Change. 126: 365-379.

Massarirambi, M. T., V. Chingwara and V. D. Shongwe. 2009. The effect of irrigation on synchronization of coffee (Coffea arabica 
L.) fl owering and berry ripening at Chipinge, Zimbabwe. Phys. Chem. Earth. 34: 786-789.

Matiello, J. B., R. Santinato, A. W. R. Garcia, S. R. A. Almeida and D. R. Fernandes. 2010. Coffee Culture in Brazil: Recommendations Manual [Cultura do Café no Brasil: Manual de Recomendações] [Port.]. Fundação Procafé, Rio de Janeiro, Brazil.

Melo, B. and L. B. Sousa. 2011. Biology of reproduction Coffea arábica. L. e Coffea canephora Pierre [Biologia da reprodução de Coffea arabica L. e Coffea canephora Pierre][Port.]. Rev. Verde. 6: 01-07.

Nazareno, R. B., C. A. S. Oliveira, C. Sanzonowicz, J. B. R. Sampaio, J. C. P. Silva and A. F. Guerra. 2003. Initial growth of Rubi coffee plant in response to nitrogen, phosphorus and potassium and water regimes [Crescimento inicial do cafeeiro Rubi em respostas a doses de nitrogênio fósforo e potássio e a regime hídrico][Port.]. Pesq. Agropec. Bras. 38: 903-910.

Paes, J. M. V., F. Andreola, C. H. Brito and E. G. Loures. 1996. Coffee straw decomposition in three soil types and their influence on the CTC and the $\mathrm{pH}$ [Decomposição da palha de café em três tipos de solo e sua influência sobre a CTC e o pH][Port.]. Rev. Ceres. 43: 674-683.

Paiva, R. N., C. H. S. Carvalho, A. N. G. Mendes, S. R. Almeida, J. B. Matiello and R. A. Ferreira. 2010. Field performance of coffee progenies (Coffea arabica L.) in Varginha, Minas Gerais State. Coffee Sci. 5: 49-58.

Partelli, F. L., M. C. Espindula, W. B. Marré and H. D. Vieira. 2014. Dry matter and macronutrient accumulation in fruits of conilon coffee with different ripening cycles. Rev. Bras. Cien. Solo. 38:214-222.

Partelli, F. L., H. V. Vieira, P. H. Monnerat and A. P. Viana. 2006. Establishment of DRIS norms for organic and conventional Conilon coffee in the State of Espírito Santo (Brazil). [Estabelecimento de normas DRIS em cafeeiro conilon orgânico ou convencional no estado do Espírito Santo] [Port]. Rev. Bras. Cien. Solo. 30: 443-451.

Pereira, L. R. Growth, production and performance of clones of the variety 'Conilon Vitória' in drought conditions and irrigated [Crescimento, produção e rendimento dos clones da variedade 'Conilon Vitória' em condições de déficit hídrico e irrigado][Port.]. Master. Dissertation, Universidade Federal do Espírito Santo, Vitória, Brazil.

Pezzopane, J. R. M., F. S. Castro, J. E. M. Pezzopane, R. Bonomo and G. S. Saraiva. 2010. Climatic risk zoning for Conilon coffee in Espirito Santo, Brazil [Zoneamento de risco climático para a cultura do café Conilon no Estado do Espírito Santo][Port.]. Cien. Agron. 41: 341-348.
Ramalho, J. C., A. S. Fortunato, L. F. Goulao and F. C. Lidon. 2013. Cold-induced changes in mineral content in leaves of Coffea spp. Identifi cation of descriptors for tolerance assessment. Biol. Plant. 57(3): 495-506.

Rena, A. B. and M. Maestri. 1985. Coffee physiology [Fisiologia do cafeeiro][Port.]. Informe Agropecu. 11: 26-40.

Rodrigues, W. P., M. Q. Martins, A. S. Fortunato, A. P. Rodrigues, J. N. Semedo, M. C. Simões-Costa, I. P. Pais, A. E. Leitão, F. Colwell, L. Goulao, C. Máguas, F. L. Partelli, E. Campostrini, P. Scotti-Campos, A. I. Ribeiro-Barros, F. C. Lidon, F. M. DaMatta and J. C. Ramalho. 2016. Long-term elevated air [CO2] strengthens photosynthetic functioning and mitigates the impact of supra-optimal temperatures in tropical Coffea arabica and C. canephora species. Glob. Change Biol. 22(1): 415-431.

Sakai, E., E. A. A Barbosa, J. M. C. Silveira and R. C. M. Pires. 2015. Coffee productivity and root systems in cultivation schemes with different population arrangements and with and without drip irrigation. Agric. Water Manage. 148: 16-23.

Santos, C. A. F., A. E Leitão, I. P. Pais, F. C. Lidon and J. C. Ramalho. 2015. Perspectives on the potential impacts of climate changes on coffee plant and bean quality. Emirates J. Food Agric. 27: 152-163.

Sarruge, J. R., R. G. Andrade, L. Gomes, S. Arzolla, E. A. Graner and E. Malavolta. 1966. Studies on the coffee mineral nutrition, XIX. Micronutrient extraction in crop varieties by the Mundo novo, Caturra Amarelo e Bourbon Amarelo [Estudos sobre a alimentação mineral do cafeeiro, XIX. Extração de micronutrientes na colheita pelas variedades Mundo novo, Caturra Amarelo e Bourbon Amarelo][Port.]. Anais da Escola Superior de Agricultura Luiz de Queiroz. São Paulo, Brazil.

Scalco, M. S., L. A Alvarença, R. J. Guimarães, C. Colombo and G. A. Assis. 2011. Irrigated and non-irrigated coffee (Coffea arabica L.) under super dense condition. Coffee Sci. 6: 193-202.

Serrano, L. A. L., V. M. Silva and E. A. Formentini. 2011. Use of organics compounds in the planting coffee Conilon trees [Uso de compostos orgânicos no plantio do cafeeiro Conilon][Port.]. Rev. Ceres. 58: 100-107.

Silva, F. C. 2009. Guide for Chemical Analysis of Soil, Plants and Fertilizers, [Manual de análises químicas de solos, plantas e fertilizantes][Port.]. 2nd ed. Embrapa Informação Tecnológica, Rio de Janeiro, Brazil.

Verdin Filho, A. C., M. A. Tomaz, R. G. Ferrão, M. A. G. Ferrão, A. F. A. Fonseca and W. N. Rodrigues. 2014. Conilon coffee yield using the programmed pruning cycle and different cultivation densities. Coffee Sci. 9: 489-494. 